\title{
SIMPLIFICATION OF THE ANALYSIS OF DRY MATTER IN FLUID MILK
}

\author{
Frederico Teixeira Correa ${ }^{1}$ \\ Felipe Furtini Haddad ${ }^{2}$ \\ José Hugo de Oliveira ${ }^{3}$
}

CORREA, F. T.; HADDAD, F. F.; OLIVEIRA, J. H. de. Simplification of the analysis of dry matter in fluid milk. Arq. Ciênc. Vet. Zool. UNIPAR, Umuarama, v. 22, n. 4, p. 115-118, out./dez. 2019.

\begin{abstract}
This study aims to evaluate a simpler methodology for determination of dry matter in three types of milk. The treatments consisted of three methodologies: AOAC (Association of Official Agricultural Chemists), characterized by the drying in porcelain capsules and pre-heating; use of analytical sand in the process of drying, as well as a simplified methodology characterized by drying in Petri dishes without analytical sand and pre-heating proceeding. The statistical analysis was performed with F test ( $5 \%$ significance level), Pearson's correlation and Lin's concordance correlation coefficient. All methodologies showed precision and accuracy in the measurement of the dry matter in milk, however, the simplified methodology was superior in material savings and shorter time consumption for the analysis.
\end{abstract}

KEYWORDS: Accuracy. Analytical methodologies. Composition. Milk.

\section{SIMPLIFICAÇÃO DA ANÁLISE DE MATÉRIA SECA EM LEITE FLUÍDO}

RESUMO: Este estudo teve como objetivo avaliar metodologia simplificada de determinação de matéria seca em três tipos de leite. Os tratamentos consistiram de três metodologias: AOAC (Association of Official Agricultural Chemists), caracterizada pela secagem em cápsulas de porcelana e pré-secagem; uso de areia analítica no processo de secagem e utilização de metodologia simplificada baseada no uso de placas de Petri com secagem direta em estufa, sem o uso de areia analítica e procedimento de pré-secagem. A análise estatística envolveu o teste F ao nível de significância de 5\%, correlação de Pearson e coeficiente de concordância de Lin. Todas as metodologias mostraram acurácia na determinação da matéria seca para todos os tipos de leite, mas a metodologia simplificada foi superior em economia e menor tempo de análise.

PALAVRAS-CHAVE: Acurácia. Composição. Leite. Metodologias analíticas.

\section{SIMPLIFICACIÓN DEL ANÁLISIS DE MATERIA SECA EN LECHE FLUIDA}

RESUMEN: Este estudio tuvo como objetivo evaluar la metodología simplificada de determinación de materia seca en tres tipos de leche. Los tratamientos consistieron en tres metodologías: AOAC (Association of Official Agricultural Chemists), caracterizada por pre-secado y secado en cápsulas de porcelana; uso de arena analítica en el proceso de secado y utilización de metodología simplificada basada en el uso de placas de Petri con secado directo en invernadero, sin el uso de arena analítica y procedimiento de pre secado. El análisis estadístico involucró la prueba $\mathrm{F}$ al nivel de significancia del 5\%, correlación de Pearson y coeficiente de concordancia de Lin. Todas las metodologías mostraron precisión en la determinación de la materia seca para todos los tipos de leche, pero la metodología simplificada fue superior en economía y menor tiempo de análisis.

PALABRAS CLAVE: Exactitud. Composición. Leche. Metodologías analíticas.

\section{Introduction}

The laboratorial activities are characterized by the high costs due to a monopoly of industries that produces reagents and equipment at high prices. This fact penalizes the attempts of small laboratories and research facilities to develop their investigations. Analyzes involving milk and milk products are an example.

Milk is a highly nutritious type of food formed in the udders of dairy cows and stands out for its participation in the world economy. The global cow milk production in 2016 was approximately 495 million tons, the European Union being the main producer, with 152.0 million tons (USDA, 2017). The dry matter of milk is considered determinant for quality and yield in the production of dairy products.
When determining the dry matter of milk and other food types, the addition of analytical sand in porcelain capsules can avoid blistering and crusting during the evaporation process (BRADLEY JR., 2010). The problem, in this case, is the labor expended in manufacture or the high cost of acquiring it. By the 925.23 method (AOAC, 1998), fluid milk is pre-heated in the drying vessel with the sample of milk on the steam bath for 10-15 minutes and placed in oven at $102 \pm$ $2{ }^{\circ} \mathrm{C}$ until it reaches constant weight, which extends the time of analysis. Usually, methods for quick determination of dry matter are simpler to perform and allow for more evaluations in shorter periods of time (BAVKAR; KOSMER, 2002) than official methods. The use of electronic equipment allows rapid measurements, however, doing so raises the problem of the cost of its acquisition. 
In recent years, research works carried out in countries such as Brazil, Argentina and Paraguay have shown irregularities in milk quality, mainly as for density parameters, freezing point, fat and nonfat dry matter and those research works highlight the importance of the dry matter as an indication of quality (DOMARESKI et al., 2010; CORREA; CAMPOS; PINTO 2015). To determine the true value of the dry matter of milk, it is necessary that lab tests be accurate and precise.

Aiming to propose an alternative methodology for dry matter determination, this study compared the determination of dry matter in three types of fluid milk by a simplified methodology with the official methodologies described by AOAC (1998) and Pereira et al., (2001).

\section{Material and methods}

\section{Dry matter determination}

To perform the assays, five packages of each type of milk (UHT whole milk, pasteurized whole milk and UHT skimmed milk) were acquired in the market. Every package was homogenized with 25 package inversions (VITTORI et al., 2008) before the analysis. The weighing was performed with an analytical balance with precision of $0,0001 \mathrm{~g}$ (Mettler Toledo®).

For the AOAC (1998) method, $5 \mathrm{~g}$ of milk were collected for each determination, pre-warmed into capsules on steam bath for 10-15 minutes and then, dried in the oven at $102 \pm 2{ }^{\circ} \mathrm{C}$ until a constant value between weighing was obtained. In this process, porcelain capsules without analytical sand were used. By the method described by Pereira et al. (2001), aliquots of $5 \mathrm{~g}$ of milk were placed into porcelain caps and Petri dishes with analytical sand, and the drying was performed in oven at $102 \pm 2{ }^{\circ} \mathrm{C}$. Lastly, the samples were dried into a $9 \mathrm{~cm}$-diameter Petri dishes, without analytical sand, directly inside the oven at $102 \pm 2{ }^{\circ} \mathrm{C}$ (simplified method).

While oven drying, temperature control was carefully observed to avoid burning of the samples (in addition to the oven thermometer, two more thermometers were placed in the interior, at the same level of the samples, to make sure that the temperature is $102{ }^{\circ} \mathrm{C}$ ). Petri dishes and capsules, both with and without sand, were dried in oven and cooled in desiccator, prior to every method application. All samples were placed on the same shelf and distributed randomly in the interior of the oven to avoid the effect of heating of the walls and uneven drying, with a minimal distance of $10 \mathrm{~cm}$ of the walls of oven. The samples were placed in the oven only when its temperature reached $102^{\circ} \mathrm{C}$.

Treatments 1 to 4 were designed as follows:

-Treatment 1 (T1): AOAC (1998), method of reference;

-Treatment 2 (T2): Pereira et al. (2001), porcelain capsule with analytical sand;

-Treatment 3 (T3): Pereira et al. (2001) Petri dish with analytical sand;

-Treatment 4 (T4): Petri dish without analytical sand (simplified method).

\section{Experimental design and statistical analysis}

The experiment was conducted in a completely randomized design (CRD) with five repetitions per treatment (each package is a repetition). For each treatment, we used three types of milk (UHT whole milk, pasteurized whole milk and UHT skimmed milk). For each package, the analyses were performed in triplicate, totalizing 15 observations per treatment, to each type of milk.

To evaluate the results, an analysis of variance (ANOVA) was carried out using the $\mathrm{R}$ statistical program (R DEVELOPMENT CORE TEAM, 2013). The Pearson's correlation coefficient and Lin's concordance correlation coefficient (LIN, 1989) were performed with the computer program Excel 2010 and Analyse-it (Microsoft巴).

\section{Results and discussion}

The ANOVA indicated no significant differences among treatments for the three types of milk. Table 1 exhibits the results of Lin's concordance correlation coefficient (CCC), Pearson's correlation coefficients (PCC) and the average of dry matter (DM) in percentage of the treatments for the UHT whole milk, UHT skimmed milk and pasteurized whole milk. The reference was the T1.

Table 1. Lin's correlation coefficients (CCC) and Pearson correlation coefficients (PCC) of the treatments, with reference to the AOAC method (1998) and the media of dry matter (DM) for each treatment.

\begin{tabular}{|c|c|c|c|c|}
\hline Analysis & $\begin{array}{l}\text { Comparison } \\
\text { of treatments }\end{array}$ & U.W. & U.S. & P.M. \\
\hline \multirow{3}{*}{ PCC } & $\mathrm{T} 1 * \mathrm{~T} 2$ & 0,96 & 0,96 & 0,99 \\
\hline & $\mathrm{T} 1 * \mathrm{~T} 3$ & 0,92 & 0,97 & 0,99 \\
\hline & $\mathrm{T} 1 * \mathrm{~T} 4$ & 0,98 & 0,97 & 0,99 \\
\hline \multirow{3}{*}{$\mathrm{CCC}$} & $\mathrm{T} 1 * \mathrm{~T} 2$ & 0,87 & 0,84 & 0,95 \\
\hline & $\mathrm{T} 1 * \mathrm{~T} 3$ & 0,89 & 0,82 & 0,95 \\
\hline & $\mathrm{T} 1 * \mathrm{~T} 4$ & 0,97 & 0,93 & 0,93 \\
\hline ANOVA & Treatment* & U.W & U.S. & P.M. \\
\hline \multirow{4}{*}{$\begin{array}{c}\text { Average values } \\
(\%)\end{array}$} & $\mathrm{T} 1$ & 11,77 & 9,24 & 11,46 \\
\hline & $\mathrm{T} 2$ & 11,81 & 9,19 & 11,39 \\
\hline & $\mathrm{T} 3$ & 11,79 & 9,33 & 11,49 \\
\hline & $\mathrm{T} 4$ & 11,80 & 9,19 & 11,49 \\
\hline $\begin{array}{l}\text { Coefficient of } \\
\text { variation }(\%)\end{array}$ & & 1,05 & 3,26 & 5,81 \\
\hline \multicolumn{5}{|c|}{$\begin{array}{l}\text { * no significant difference among treatments in the ANOVA for the } \\
\text { three types of milk in } 5 \% \text { significance level } \\
\text { U.W.: UHT whole milk } \\
\text { U.S.: UHT skimmed milk } \\
\text { P.M.: pasteurized whole milk }\end{array}$} \\
\hline
\end{tabular}

According to the statistical analysis (test $\mathrm{F}$ with 5\% significance level), the means of treatment makes no significant difference among the three types of milk. The results indicated that the average values obtained from the drying methodologies were similar. For UHT whole milk, the average values of dry matter are between 11,77 and $11,81 \%$; for UHT skimmed milk the average values is between 9,19 and $9,33 \%$ and the pasteurized milk, between 11,39 and 11,49\%. Similar obtained values of dry matter after the drying process, demonstrate that all methodologies are equivalent. When comparing different drying methodologies (traditional and sim- 
plified), Correa, Correa and Abreu (2016) concluded that the differences among results were not significant, which means any of them can be used in the determination of dry matter in dairy products. The simplified method was the most efficient regarding drying speed, lower cost, and ease of performing.

In addition to the results of ANOVA, through the analysis of PCC and CCC, it can be inferred that the simplified methodology features precision and accuracy in the determination of the dry matter, as compared with the T1. The PCC is a measure of precision and the CCC a measure of accuracy. By analyzing the PCC of every method, their accuracy and precision is verified, which allows one to choose the most advantageous methodology.

For pasteurized milk, a value of 0.99 was obtained for all treatment methods, indicating high correlation among T2, T3, T4 and T1. In the case of UHT whole milk, T3 showed the lowest correlation value (0.92) when compared to the T1. As for the other treatments, the PCC was 0.96 and 0.98 for $\mathrm{T} 2$ and $\mathrm{T} 4$ respectively, indicating that $\mathrm{T} 4$ has the highest correlation with the T1. For UHT skimmed milk, the PCC values were $0.96(\mathrm{~T} 1 * \mathrm{~T} 2)$ and 0.97 for the other treatments, considering $\mathrm{T} 1$ as reference.

The results for CCC suggest minor variations between treatments. The values of CCC for the three types of milk under the different treatments were between 0.82 and 0.97. For UHT skimmed milk, a lower value for the CCC was obtained, especially when under T3. For this type of milk, CCC values were between $0.84,0.82$ and 0.93 for T2, $\mathrm{T} 3$ and $\mathrm{T} 4$, respectively, the $\mathrm{T} 1$ being the reference. In the case of pasteurized milk, the values were between 0.93 and 0.95 , indicating a high accuracy of the methodologies. The small variations between methods and the types of milk can be explained as mere random phenomena.

Innovation and improvement of the analyses should be a continuous process for industry and research centers, in view that money and time are involved in the activites. Little information can be found about optimization of drying methodologies. Venturoso et al., (2007), studying ways of determining milk and dairy products nutrients concluded that the results of physicochemical analysis under the classic methodology and ultrasound are comparable. The results for nonfat dry matter, protein, fat and density obtained by ultrasound correlate with the official methods results in the majority of situations. Ahn et al. (2014) studying different methodologies of drying of feed ingredients, observed that drying at $135^{\circ} \mathrm{C}$ for $2 \mathrm{~h}$ is not appropriate for determining the moisture content in whey permeate, whey powder or distillers dried grains with soluble as well as the mixed diet containing these ingredients. The oven-drying method at $105^{\circ} \mathrm{C}$ for 5 to $6 \mathrm{~h}$ appears to be appropriate, in contrast with drying samples at $135^{\circ} \mathrm{C}$ for $2 \mathrm{~h}$.

\section{Conclusion}

All methods indicated similar dry matter values in relation to the official method $\mathrm{AOAC}$, besides precision and accuracy in the Pearson correlation coefficient and Lin agreement coefficient tests, respectively, for all types of milk. These results allow researchers to choose the one that best fits in their work routine, being the simplified method the recommended as an alternative, due to the easiness of performing.

\section{References}

AHN, J. Y. et al. Comparison of oven-drying methods for determination of moisture content in feed ingredients. AsianAustralasian Journal of Animal Sciences. v. 27, n.11, p. 1615-1622, 2014

AOAC. Milk dry matter method, method $\mathrm{n}^{\circ}$ 925.23. In: Official methods of analysis, v. 16 n.4, p. 3-120. 1998.

BAVKAR, D.; KOSMER, T. Determination of alcohol and total dry extract in slovenian wines by empirical relations. Food Technology and Biotechnologies, v. 40 n. 4, p 321$329,2002$.

BRADLEY JR, R. L. Moisture and Total Solids Analysis in S. S. Nielsen (Ed.), Food Analysis, West Lafayette, v. 4, p. $85-104,2010$

CORREA, F. T.; CAMPOS, S. A. S.; PINTO, S. M. Presença de antibióticos, conservantes e reconstituintes em leite UHT e pasteurizado. Demetra, v. 2, p. 289-98, 2015.

CORREA, F. T.; CORREA, P. T.;ABREU,L. R. Determination of the total solids of fermented milk, UHT milk, and milk cream: evaluation of an simplified methodology. Extensio: Revista Eletrônica de Extensão, Florianópolis, v. 13, n. 24 p. 83-93, 2016.

DOMARESKI, J. L. et al. Physico-chemical and microbiological evaluation of UHT milk commercialized in three Mercosul countries (Brazil, Argentina and Paraguay). Archivos Latinoamericanos de Nutricion, v. 60 n. 3, p. 261-269, 2010.

PEREIRA, D. B. C. et al. Físicoquímica do leite e derivados: métodos analíticos. 2. ed. Juiz de Fora: EPAMIG. 2001. 234 p.

LIN, L. I. A concordance correlation coefficient to evaluate reproducibility. Biometrics, Washington, v. 45, n. 1 p. 255 $68,1989$.

R DEVELOPMENT CORE TEAM. R, a language and environment for statistical computing, reference index version 2.13.0. R Foundation for Statistical Computing, Vienna, Austria. Retrieve from: www.R-project.org. 2013. Access 10 dec. 2018.

USDA (United States Department of Agriculture). Cows Milk Production and Consumption: Summary For Selected Countries. 2016. Retrieve from https://apps.fas. usda.gov/psdonline/circulars/dairy.pdf. Access in 11-122018.

VITTORI, J. et al. Microbiological quality of UHT goat milk: research of bacteria Staphylococcus, Bacillus and Clostridium genus. Ciência Rural, v. 38, n. 3, p. 761-765, 2008.

VENTUROSO, R. C. et al. Determination of the physical- 
chemical composition of dairy products: exploratory study to compare the results obtained by classic methodology and by ultra-sound. Revista Brasileira de Ciências Farmaceuticas, v. 43, n. 4, p. 607-613, 2007.

Recebido em: 17.05.2019.

Aceito em: 27.12.2019. 